\title{
Long-term corticosteroid therapy for patients with severe coronavirus disease 2019 (COVID-19)
}

George Calcaianu', Samuel Degoul ${ }^{3}$, Thibault Payen", Bénédicte Michau", Mihaela Calcaianu², Bree Lawson², Didier Bresson², Didier Debieuvre $^{1}$

${ }^{1}$ Department of Pulmonology, Groupe Hospitalier de la Région de Mulhouse et Sud Alsace (GHRMSA), Mulhouse, France

${ }^{2}$ Department of Cardiology, Groupe Hospitalier de la Région de Mulhouse et Sud Alsace (GHRMSA), Mulhouse, France

${ }^{3}$ Deparment of Clinical Research, Groupe Hospitalier de la Région de Mulhouse et Sud Alsace (GHRMSA), Mulhouse, France

${ }^{4}$ Departement of Internal Medicine, Groupe Hospitalier de la Région de Mulhouse et Sud Alsace (GHRMSA), Mulhouse, France

Corresponding author:

George Calcaianu, Department of Pulmonology, Groupe Hospitalier de la Région de Mulhouse et Sud Alsace (GHRMSA)

20 avenue du Dr René Laennec, 68100 Mulhouse, France

Email: calcaianugeorge@gmail.com

Tel: +33 389647028; Fax: + 33389647377 
Keywords: corticosteroid; methylprednisolone; prednisolone; COVID-19; SARSCoV2;

Running title: Long-term Methylprednisolone for COVID-19

40-word summary: earlier and longer corticosteroid therapy with methylprednisolone could reduce the mortality and/or rate of ICU admission by $26 \%$ in patients with severe COVID-19, hospitalized in conventional medical ward. 
Background: Low dose of dexamethasone reduced mortality in hospitalized COVID-19 patients who required respiratory support. Less is known about the efficacy of other corticosteroids in severe COVID-19 patients. This study was designed to determine if longer and earlier corticoid therapy in severe COVID-19 patients is associated with reduced mortality and/or reduced rate of ICU admission for worsening of respiratory state.

Methods: We performed a retrospective study with patients aged $\geq 18$ years, with epidemiological and/or radiological suspected COVID-19, hospitalized in a regional hospital GHRMSA Mulhouse, France. Twenty-three patients received methylprednisolone (MP) as compassionate use, $1 \mathrm{mg} / \mathrm{kg} /$ day for seven days followed by prednisolone at a gradually reduced dosage, for 4 to 6 weeks. MP was started one week after COVID-19 symptoms first appeared. The primary composite outcome was mortality and/or ICU admission during hospitalisation.

Results: Between March $14^{\text {th }}$ to June $5^{\text {th }} 2020,255$ patients were screened, 181 were included, and 92 were analysed, 23 patients treated with MP and 69 received standard care. SARS-CoV2 infection was confirmed by reverse transcriptase polymerase chain reaction (RT-PCR) in $82.3 \%$. The overall composite outcome was higher in the control group: $42 / 69$ patients (60.9\%) versus $8 / 23(34.8 \%)$ in the interventional group $(p=0.018)$. The correction of lymphopenia between days 1 to 7 was associated with better outcome $(p=0.006)$.

Conclusion: These results suggest that earlier and longer corticosteroid therapy with methylprednisolone could reduce the mortality and/or rate of ICU admission in patients with severe COVID-19, hospitalized in conventional medical ward. 
Coronavirus Disease 2019 (COVID-19) was first reported in late December 2019, in Wuhan, China. Currently, there are over $213 \square$ million confirmed cases worldwide and more than 4.4 million deaths due to SARS-CoV2 infection. The Grand-Est region was one the most affected by this pandemic in France, with more than 3700 deaths. The most common cause of death in COVID-19 patients is respiratory failure with acute respiratory distress syndrome (ARDS). Several studies reported high mortality rate among in-hospital COVID-19 patients $(1,2)$.

The pathophysiology of severe COVID-19 is characterized by acute extensive pneumonia complicated by inflammatory infiltrates, micro thrombosis and finally diffuse alveolar damage. The lung injury is not only associated to virus-induced injury, but also to the immune response triggered by COVID-19 with activation of pro-inflammatory cytokines (3-5). It has been observed that a subgroup of COVID-19 patients have markedly elevated inflammatory markers such as C-reactive protein, ferritin and interleukin 6 (6-8). Systemic corticosteroids have an important anti-inflammatory effect and are frequently used as additional treatment for viral pneumonia.

Results from a large randomized controlled trial (RCT) (RECOVERY Trial), using dexamethasone $6 \mathrm{mg}$ once daily for 10 days, found that the absolute risk of death was reduced by $12,1 \%$, mostly in critically ill COVID-19 patients (9) .

However, the question about the efficacy of other systemic corticosteroids such as methylprednisolone (MP), a common steroid used in clinical practice, is still debated (10-12). However, some data are consistent with the efficacy of corticosteroids independent of the formulation (13). The optimal dose and duration of treatment are still questionable. 
The recently published data from the METCOVID randomized controlled trial showed that the use of MP at $1 \mathrm{mg} / \mathrm{kg} /$ day, during 5 days, in critical COVID-19 patients did not improve prognosis (10). The authors of this study hypothesized that a possible explanation of this result is the shorter duration of corticoid treatment and a late start of MP treatment in the evolution of disease. A recent review of corticosteroid therapy studies showed a delayed viral clearance for SARS-CoV1 and MERS-CoV infections. It is likely that corticosteroid therapy needs to be prescribed more than 5 days or until clinical improvement because of the risk of increased viral load that could lead to increased inflammation after the withdraw of corticosteroid therapy (14).

Several biological markers have been identified to modulate the course of COVID-19 (15). A recent meta-analysis showed that a decrease in lymphocytes count or lymphocyte to C-reactive protein ratio (LCR) discriminate severe cases of COVID-19 (16).

We designed a retrospective study to evaluate if early use of MP (7 days after COVID-19 symptoms first appeared) and for a longer duration is associated to a reduced risk of death or admission in intensive care unit (ICU), for patients with severe COVID-19 infection, hospitalized in Pulmonary or Cardiology Department of the Groupe Hospitalier de la Région de Mulhouse et Sud Alsace (GHRMSA), Mulhouse, France.

After collegial discussion between pneumologist and ICU staff and according to an internal protocol, 23 patients were treated by MP $1-2 \mathrm{mg} / \mathrm{kg} /$ day during 7 days followed by prednisolone at a gradually reduced dosage, for 4 to 6 weeks. The corticosteroid treatment was started one week after COVID-19 symptoms first appeared. All cases of COVID-19 patients that required oxygen were treated with preemptive intravenous cefotaxime ( $1 \mathrm{~g}, 3$ times per day for 7 days). 
medRxiv preprint doi: https://doi.org/10.1101/2021.08.30.21262824; this version posted September 7, 2021. The copyright holder for this preprint (which was not certified by peer review) is the author/funder, who has granted medRxiv a license to display the preprint in perpetuity. All rights reserved. No reuse allowed without permission.

The criteria for ICU admission/intubation were worsening of respiratory failure despite maximal oxygen therapy, hemodynamic instability and neurological deterioration.

We also evaluated if the normalization of lymphocyte count between day 1 and day 7 could predict the prognosis. 


\section{Methods}

This observational study was conducted in the Pulmonary and Cardiology department of a 2409-bed regional hospital (Mulhouse-Sud Alsace Hospital, France). This study complied with the Declaration of Helsinki and was approved by the Institutional Review Board of the French Learned Society for Respiratory Medicine "Société de Pneumologie de Langue Française" (CEPRO 2020-055).

\section{Participants}

255 patients were admitted in the Pulmonary and Cardiology department between March $14^{\text {th }}$ to June $5^{\text {th }} 2020$, with confirmed SARS-COV2 infection and/or acute respiratory distress (bilateral pulmonary infiltrates on chest x-ray on CT-scan and need for standard oxygen therapy between $1 \mathrm{~L} / \mathrm{min}$ and $15 \mathrm{~L} / \mathrm{min})$.

The exclusion criteria were: (1) absence of laboratory confirmation of SARSCOV-2 infection and absence of typical COVID-19 CT scan profile, (2) death in the first 48 hours after admission, (3) transfer to ICU in the first 48 hours after hospitalization (these patients did not have the opportunity of corticosteroids treatment).

Finally, 181 patients were included and retrospectively assigned to intervention group if they were treated by corticosteroids during hospital stay, or to the control group, otherwise. 


\section{Procedures}

Clinical data, including morphological characteristics, comorbidities, vital signs and provided treatments was manually collected. Laboratory data at admission and discharge was automatically extracted from our health information system. Data management was performed in a reproductible way.

\section{Outcomes}

The primary outcome was ICU admission, or death, during hospitalisation. A "do not resuscitate" (DNR) decision has sometimes been made, after collegial discussion between pulmonologists and ICU staff at admission, taking into account the patient's opinion, age and comorbidities. Secondary outcomes related to corticosteroid therapy included 28-day all-cause mortality. The relationship between the outcome and the correction of lymphopenia or evolution of lymphocytes to C-reactive protein ratio (LCR), between days 1 to 7 , was studied for exploration purpose.

Statistical analysis

Descriptive analysis was expressed as numbers and proportions for categorical variables, and as means and standard deviations or median and quartiles for quantitative variables with nearly normal or non-normal distribution, respectively. No particular handling of missing data was performed, and analyses were restricted to complete cases.

Bivariate comparisons of covariates between treated (corticosteroid therapy) and control group on the one hand, and relation between each covariates and outcomes in the other hand, were performed trough Chi square test for categorical covariates, and 
parametric (t test) or non-parametric (Wilcoxon) tests for quantitative ones, depending on their distribution.

To restore comparability between the two groups, a 1:3 nearest neighbour propensity score matching was conducted, based on three covariates: age, hypertension or diabetes comorbidity, and maximal dose of oxygen therapy in first 48 hours.

We stratified the severity of respiratory failure in three categories: severe pneumonia defined patients requiring more than $10 \mathrm{~L} / \mathrm{min}$ of oxygen flow, moderate pneumonia defined patients requiring between 5 and $10 \mathrm{~L} / \mathrm{min}$ of oxygen flow and mild pneumonia defined patients requiring less than $5 \mathrm{~L} / \mathrm{min}$ of oxygen flow.

The primary outcome was first analysed using a conditional logistic regression model applied on the matched groups. Several sensitivity analyses were carried out: (1) logistic regression performed on the whole population adjusted on the propensity score, (2) 'naive' logistic regression on the whole population adjusted on the same covariates than those used for matching. Same analyses were used for 28-day mortality.

The evolution of lymphocytes count and lymphocytes to CRP ratio, between days 1 to 7 , was evaluated for description purpose.

Analyses were performed using $\mathrm{R}$ version 3.5 .2 for Linux 64 bits. All statistic tests were two-sided and a significance level of 0.05 was considered. Odds ratio were reported with their $95 \% \mathrm{Cl}$. 


\section{Results}

Population characteristics

Out of 255 patients, hospitalized in our departments between March $14^{\text {th }}$ to June $5^{\text {th }} 2020,181$ met the inclusion criteria, out of which $23(12.7 \%)$ of them received corticosteroids during hospitalization. Figure 1 shows the study profile and the reasons for exclusion.

We found that the patients treated by corticosteroids had a more severe respiratory failure, they were more likely to have cardiovascular comorbidities and they received more likely a DNR decision. We did not find any differences in terms of age, sex, BMI, respiratory comorbidities, inflammatory status, lymphocyte count, Ddimers dosage, NT-proBNP or Troponin level or delay of COVID-19 symptoms (Table 1). The majority of patients (82.3\%) had laboratory confirmation SARS-COV-2 infection. The remaining patients presented a typically COVID-19 CT scan profile.

In order to evaluate the efficacy of corticosteroid therapy, we compared the intervention group (23 patients) to a control group (69 patients) adjusted in terms of age, degree of respiratory impairment and history of arterial hypertension and diabetes. The characteristics of the adjusted and non-adjusted study population are presented in Table 1. In the case of non-adjusted model (181 patients), no significant difference was seen between patients regarding the primary or secondary outcomes.

In the adjusted model (92 patients), 50 patients met the primary outcome of death or ICU admissions because of respiratory impairment (25 of whom died and 25 of whom were admitted in ICU). The overall composite outcome (death or ICU admission during hospitalisation) was $42 / 69(60.9 \%)$ in the control group versus $8 / 23(34.8 \%)$ in 
the group of patients treated by systemic corticosteroids $(p=0.018$; odds ratio $0.24 ; 95 \%$ CI 0.07-0.79; with absolute risk of death or ICU admission reduced by $26 \%$ and relative risk of death or ICU admission reduced by $43 \%$ ) (Figure 2). In a subgroup analysis, we found a trend to higher absolute benefit among patients with higher oxygen flow (reduction of composite outcome by $39 \%$ for patients requiring an oxygen flow higher than $10 \mathrm{~L} / \mathrm{min}$, by $13 \%$ for patients requiring an oxygen flow between 5 and $10 \mathrm{~L} / \mathrm{min}$ and $11 \%$ for patients requiring an oxygen flow less than $5 \mathrm{~L} / \mathrm{min}$ ) and with higher inflammatory status (reduction of composite outcome by $42 \%$ if CRP level $\geq 100 \mathrm{mg} / \mathrm{dL}$ and by $7 \%$ if CRP level $<100 \mathrm{mg} / \mathrm{dL})$.

Regarding secondary outcome, the 28-days mortality was not different between the two groups (31.9\% in the control group vs. 30.4\% in the interventional group, $p=0.9)$. The correction of lymphopenia between day 1 to day 7 was associated to better composite outcome $(p=0.006$; odds ratio $0.17,95 \% \mathrm{Cl} 0.05-0.61$; with absolute risk reduction by $28 \%$ and relative risk reduction by $75 \%$ ) (Table 2). Higher LCR at day 7 seemed to be associated with better outcome (Figure 3). 


\section{Discussion}

The results of this study indicate that early treatment with MP, at $1-2 \mathrm{mg} / \mathrm{kg} / \mathrm{day}$ during 7 days, followed by prednisolone at a gradually reduced dosage, for 4 to 6 weeks is associated with reduced mortality and fewer ICU admissions for worsening respiratory state. These findings are consistent for an adjusted population (by age, hypertension or diabetes comorbidity, and maximal dose of oxygen therapy during the first 48 hours). We used this corticosteroid therapy as a compensationate treatment for a majority of patients who received a DNR decision, based on patient's wishes, age and comorbidities. Dexamethasone is now used commonly and considered as part of standard of care for oxygen requiring COVID-19 patients (9).

Less is known about the efficacy of other corticoid molecules in COVID-19 patients. The recently published METCOVID randomized trial showed that MP, at 1 $\mathrm{mg} / \mathrm{kg} /$ day during 5 days, was not associated with lower rate of mortality in severe COVID-19 patients. One reason could be the shorter duration of corticoid treatment and a late start of MP therapy at an advanced stage of the disease. However, a subgroup analysis found a lower mortality rate for patients over 60 years old who received MP and these patients presented a higher level of inflammation status, with higher CRP levels (10).

In our study, we found a reduced rate of mortality and/or ICU admissions, with an absolute risk of composed outcome reduced by $26 \%$. This result could be explained by the early start of corticosteroid therapy (during the second week of the disease) and the longer duration of treatment (4 to 6 weeks at a gradually reduced dose). A recent review of corticosteroid therapy studies showed a delayed viral clearance for SARS-CoV1 and 
MERS-CoV infections which can lead to more inflammation after the withdraw of corticosteroids (14).

The results from RECOVERY trial indicated a mortality benefit, mostly in severe cases of COVID-19 (9). Our study reaffirms these findings, with better results in case of patients receiving high oxygen flow and having a higher inflammatory status.

It is known that lymphopenia and low lymphocytes to C-reactive protein ratio at baseline could predict the severity of disease in patients with COVID-19 (16-18). We found that the correction of lymphopenia between day 1 to day 7 is associated to better prognosis and could be a predictive marker of better evolution of the disease. Secondly, higher lymphocytes to C-reactive protein ratio, between day 1 to day 7 , seemed to be associated with better outcome.

Observational studies suggest a higher risk for secondary bacterial or fungal infections following the use of corticoids in viral infections $(19,20)$. Our study was not designed to evaluate the risk of infection secondary to corticosteroid treatment. Although, all the patients included in our analysis were hospitalized, monitored and treated by ceftriaxone in association to macrolide. We did not noticed nay fungal or bacterial infection in our population of study.

This study had several limitations. Our study analyses retrospectively a small sample size and therefore it is subject to confounding and bias. Since this study was done in a single center, these results cannot be generalized. However, we tried to reduce the bias and confounders by restoring comparability between the two groups, by 1:3 nearest neighbour propensity score, based on three covariates: age, hypertension or diabetes comorbidity, and maximal dose of maximal oxygen therapy in first 48 hours. Moreover, the patients treated by MP were more likely to have cardiovascular 
comorbidities. During the first 2 months of pandemic in France, we used this corticosteroid regime as a compassionate use and therefore this analysis is not based on a randomized allocation of therapy. Therefore, these results need to be confirmed in a larger, prospective study.

Last, due to limited number of patients we could not assess the effect of corticosteroid treatment on the respiratory functional recovery.

In conclusion, the use of methylprednisolone, at $1-2 \mathrm{mg} / \mathrm{kg} / \mathrm{day}$ during 7 days followed by prednisolone at a gradually reduced dosage for 4 to 6 weeks, seemed to improve the prognosis (the mortality and/or ICU transfer) in COVID-19 patients, hospitalized in a conventional medical ward. Our exploratory analysis showed that the correction of lymphopenia during the first week could be a prognostic marker of a better evolution of the disease.

Funding. This research received no specific grant from any funding agency in the public, commercial, or not-for-profit sectors.

Conflict of interest. The author(s) declare that there is no conflict of interest.

Acknowledgments. The authors thank to Clémence Perrin and Jérémie Henry for acquiring data.

Data are available on request by contacting the corresponding author, George Calcaianu, at calcaianugeorge@gmail.com. 
medRxiv preprint doi: https://doi.org/10.1101/2021.08.30.21262824; this version posted September 7, 2021. The copyright holder for this preprint (which was not certified by peer review) is the author/funder, who has granted medRxiv a license to display the preprint in perpetuity.

All rights reserved. No reuse allowed without permission. 


\section{Bibliography}

1. Docherty AB, Harrison EM, Green CA et al. Features of $20 \square 133$ UK patients in hospital with covid-19 using the ISARIC WHO Clinical Characterisation Protocol: prospective observational cohort study. BMJ. 2020 May 22;369:m1985.

2. Richardson S, Hirsch JS, Narasimhan M et al. Presenting Characteristics, Comorbidities, and Outcomes Among 5700 Patients Hospitalized With COVID-19 in the New York City Area. JAMA. 2020 26;323(20):2052-9.

3. Dolhnikoff M, Duarte-Neto AN, de Almeida Monteiro RA et al. Pathological evidence of pulmonary thrombotic phenomena in severe COVID-19. J Thromb Haemost JTH. 2020;18(6):1517-9.

4. Carsana L, Sonzogni A, Nasr A, Rossi RS et al. Pulmonary post-mortem findings in a series of COVID-19 cases from northern Italy: a two-centre descriptive study. Lancet Infect Dis. 2020;20(10):1135-40.

5. Xu Z, Shi L, Wang Y et al. Pathological findings of COVID-19 associated with acute respiratory distress syndrome. Lancet Respir Med. 2020 Apr;8(4):420-2.

6. Ruan Q, Yang K, Wang W, Jiang L, Song J. Clinical predictors of mortality due to COVID-19 based on an analysis of data of 150 patients from Wuhan, China. Intensive Care Med. 2020;46(5):846-8.

7. Huang C, Wang Y, Li X et al. Clinical features of patients infected with 2019 novel coronavirus in Wuhan, China. Lancet Lond Engl. 2020 15;395(10223):497-506. 
8. Moore JB, June CH. Cytokine release syndrome in severe COVID-19. Science. $202001 ; 368(6490): 473-4$.

9. RECOVERY Collaborative Group, Horby P, Lim WS, Emberson JR et al.

Dexamethasone in Hospitalized Patients with Covid-19 - Preliminary Report. N Engl J Med. 2020 Jul 17;

10. Jeronimo CMP, Farias MEL, Val FFA et al. Methylprednisolone as Adjunctive Therapy for Patients Hospitalized With COVID-19 (Metcovid): A Randomised, Double-Blind, Phase Ilb, Placebo-Controlled Trial. Clin Infect Dis Off Publ Infect Dis Soc Am. 2020 Aug 12;

11. Keller MJ, Kitsis EA, Arora S et al. Effect of Systemic Glucocorticoids on Mortality or Mechanical Ventilation in Patients With COVID-19. J Hosp Med. 2020 Aug;15(8):489-93.

12. Wu C, Chen X, Cai Y et al. Risk Factors Associated With Acute Respiratory Distress Syndrome and Death in Patients With Coronavirus Disease 2019 Pneumonia in Wuhan, China. JAMA Intern Med. 2020 01;180(7):934-43.

13. WHO Rapid Evidence Appraisal for COVID-19 Therapies (REACT) Working Group, Sterne JAC, Murthy S, Diaz JV et al. Association Between Administration of Systemic Corticosteroids and Mortality Among Critically III Patients With COVID-19: A Meta-analysis. JAMA. 2020 06;324(13):1330-41. 
14. Li H, Chen C, Hu F et al. Impact of corticosteroid therapy on outcomes of persons with SARS-CoV-2, SARS-CoV, or MERS-CoV infection: a systematic review and meta-analysis. Leukemia. 2020;34(6):1503-11.

15. Zhou F, Yu T, Du R et al. Clinical course and risk factors for mortality of adult inpatients with COVID-19 in Wuhan, China: a retrospective cohort study. Lancet Lond Engl. 2020 28;395(10229):1054-62.

16. Ghahramani S, Tabrizi R, Lankarani KB et al. Laboratory features of severe vs. non-severe COVID-19 patients in Asian populations: a systematic review and metaanalysis. Eur J Med Res. 2020 Aug 3;25(1):30.

17. Rodriguez-Morales AJ, Cardona-Ospina JA, Gutiérrez-Ocampo E et al. Clinical, laboratory and imaging features of COVID-19: A systematic review and metaanalysis. Travel Med Infect Dis. 2020 Apr;34:101623.

18. Okugawa Y, Toiyama Y, Yamamoto A et al. Lymphocyte-C-reactive Protein Ratio as Promising New Marker for Predicting Surgical and Oncological Outcomes in Colorectal Cancer. Ann Surg. 2020;272(2):342-51.

19. Ni Y-N, Chen G, Sun J, Liang B-M, Liang Z-A. The effect of corticosteroids on mortality of patients with influenza pneumonia: a systematic review and metaanalysis. Crit Care Lond Engl. 2019 Mar 27;23(1):99.

20. Lee FE-H, Walsh EE, Falsey AR. The effect of steroid use in hospitalized adults with respiratory syncytial virus-related illness. Chest. 2011 Nov;140(5):1155-61. 
medRxiv preprint doi: https://doi.org/10.1101/2021.08.30.21262824; this version posted September 7, 2021. The copyright holder for this preprint (which was not certified by peer review) is the author/funder, who has granted medRxiv a license to display the preprint in perpetuity.

All rights reserved. No reuse allowed without permission.

Table 1. Patients characteristics

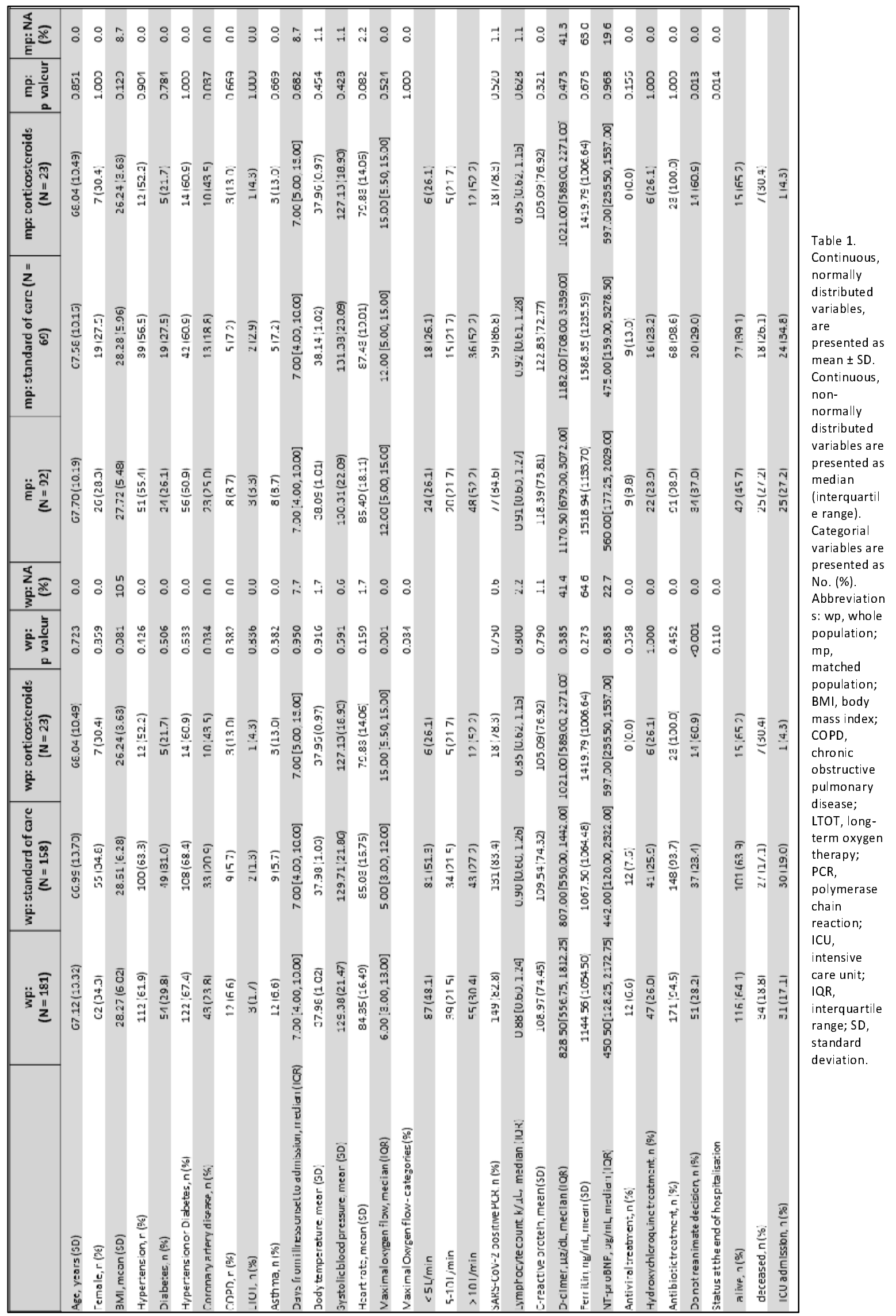


medRxiv preprint doi: https://doi.org/10.1101/2021.08.30.21262824; this version posted September 7, 2021. The copyright holder for this preprint (which was not certified by peer review) is the author/funder, who has granted medRxiv a license to display the preprint in perpetuity.

All rights reserved. No reuse allowed without permission.

Table 2. Primary, secondary and exploratory outcomes

\begin{tabular}{|c|c|c|c|c|c|}
\hline & $\begin{array}{l}\text { Total } \\
(\mathrm{N}=92)\end{array}$ & standard of care $(\mathrm{N}=69)$ & corticosteroids & OR (95\% Cl) & $p-1$ \\
\hline \multicolumn{6}{|l|}{ Primary outcome } \\
\hline Mortality and/or ICU transfer during hospitalisation, $n / N$ & $50 / 92$ & $42 / 69$ & $8 / 23$ & $0.24(0.07-0.79)$ & 0 \\
\hline \multirow[t]{2}{*}{ 28-day mortality, $\mathrm{n} / \mathrm{N}$} & $29 / 92$ & $22 / 69$ & $7 / 23$ & $0.92(0.3-2.84)$ & \\
\hline & $\begin{array}{l}\text { Total } \\
(N=95)\end{array}$ & $\begin{array}{l}\text { Normalization of lymphopenia } \\
\qquad(\mathrm{N}=33)\end{array}$ & $\begin{array}{l}\text { Non-normalization of lymphopenia } \\
\qquad(N=62)\end{array}$ & OR $(95 \% \mathrm{Cl})$ & p-1 \\
\hline
\end{tabular}


medRxiv preprint doi: https://doi.org/10.1101/2021.08.30.21262824; this version posted September 7, 2021. The copyright holder for this preprint (which was not certified by peer review) is the author/funder, who has granted medRxiv a license to display the preprint in perpetuity.

All rights reserved. No reuse allowed without permission.

Figure 1. Study profile.

Figure 2. Comparison between groups in terms of primary composite outcome

Figure 3. Exploratory outcome - evolution of lymphocytes to C-reactive protein ration, between day 1 to day 7. CRP; C-reactive protein. 
medRxiv preprint doi: https://doi.org/10.1101/2021.08.30.21262824; this version posted September 7, 2021. The copyright holder for this preprint (which was not certified by peer review) is the author/funder, who has granted medRxiv a license to display the preprint in perpetuity.

All rights reserved. No reuse allowed without permission.

Figure 1.

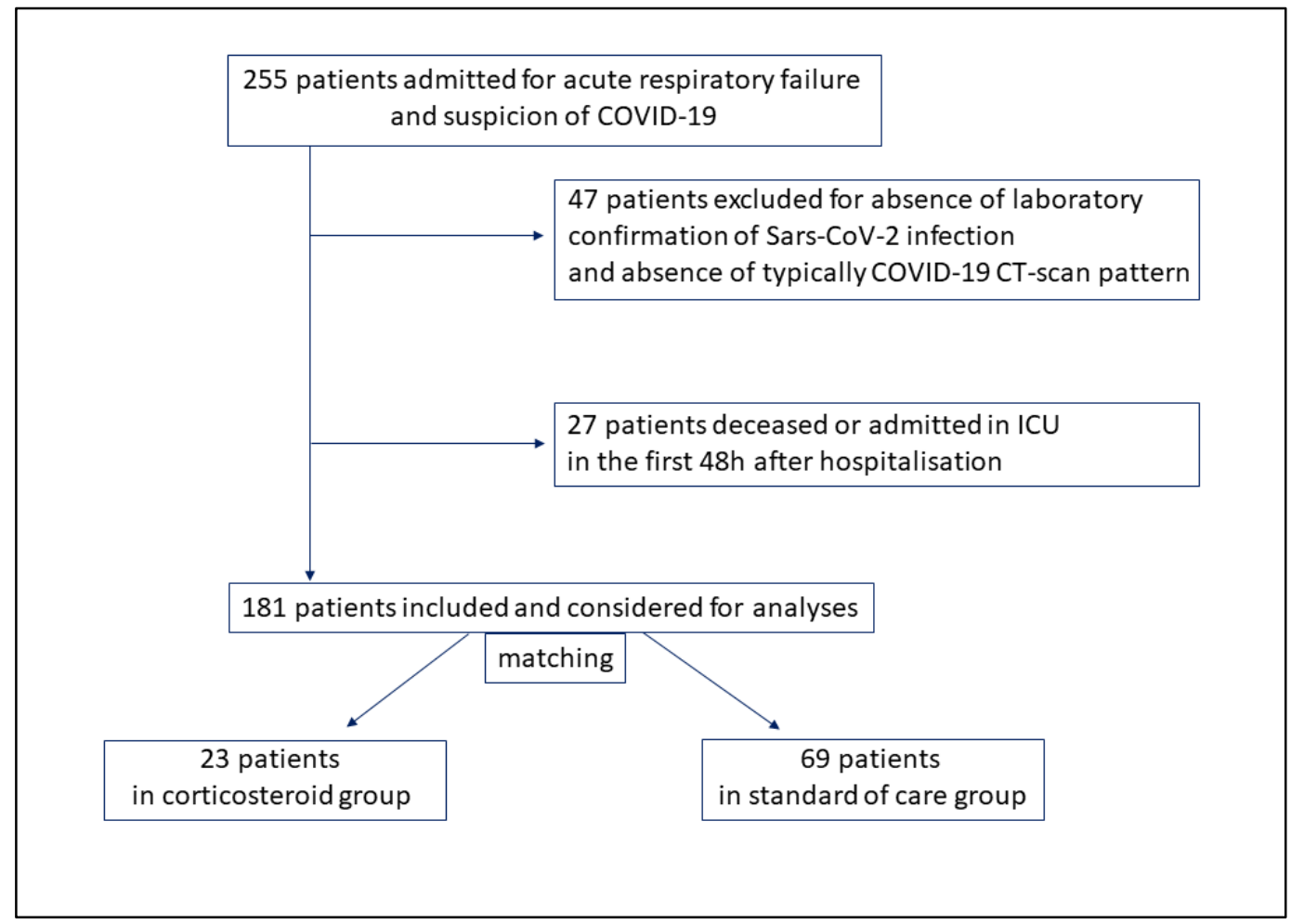

Figure 2.

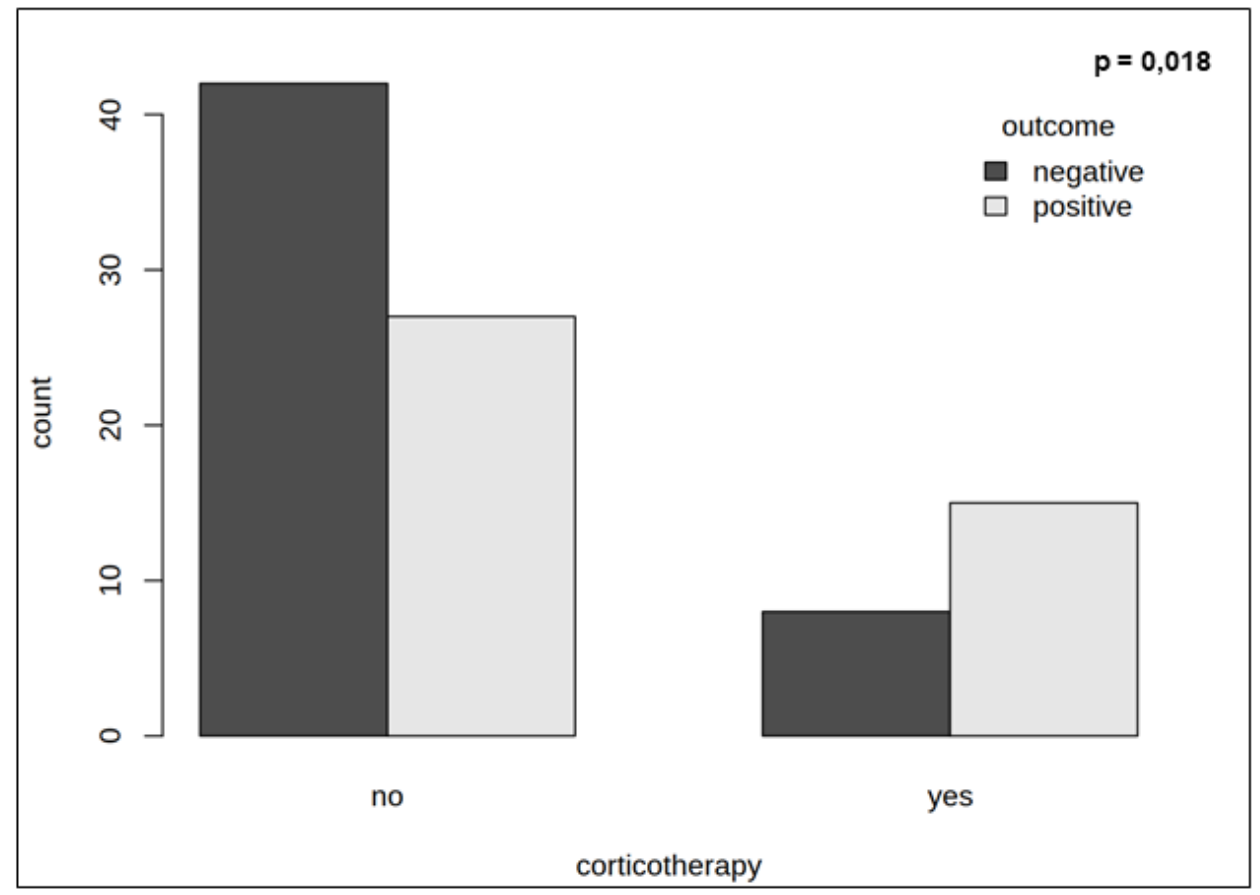


medRxiv preprint doi: https://doi.org/10.1101/2021.08.30.21262824; this version posted September 7, 2021. The copyright holder for this preprint (which was not certified by peer review) is the author/funder, who has granted medRxiv a license to display the preprint in perpetuity.

All rights reserved. No reuse allowed without permission.

Figure 3.

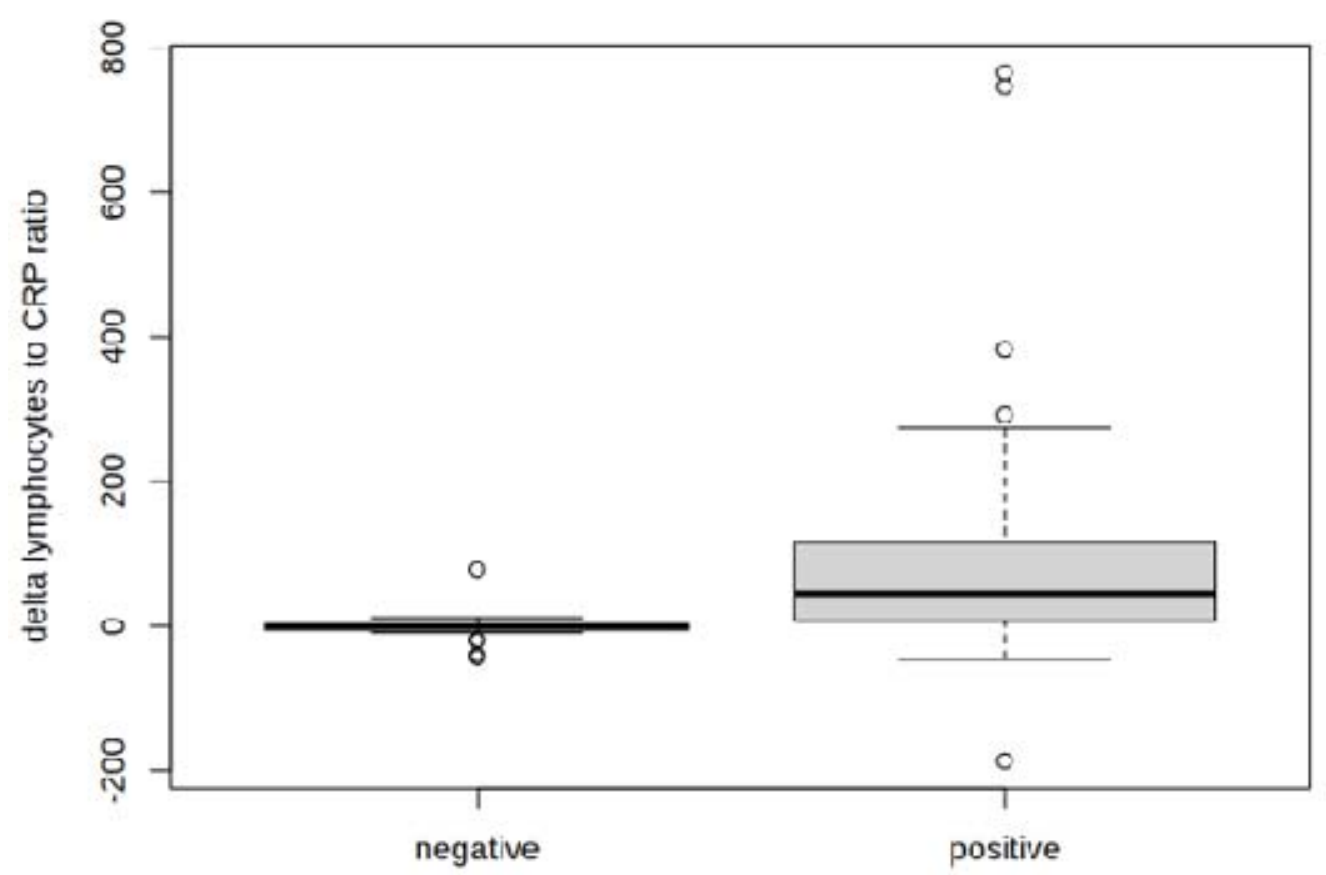

outcome 